\title{
PERCEPTION OF FRONTLINE EMPLOYEES TOWARDS CAREER GROWTH OPPORTUNITIES: IMPLICATIONS ON TURNOVER INTENTION
}

\author{
Folakemi OHUNAKIN ${ }^{1}$, Anthonia ADENIJI ${ }^{2}$, Olumuyiwa OLUDAYO ${ }^{3}$, Omotayo OSIBANJO $^{4}$
}

\author{
Covenant University, Ota, Nigeria \\ E-mails: ${ }^{1}$ folakemi.ohunakin@stu.cu.edu.ng (corresponding author); ${ }^{2}$ anthonia.adenike@covenantuniversity.edu.ng; \\ 3olumuyiwa.oludayo@covenantuniversity.edu.ng; ${ }^{4}$ ade.osibanjo@covenantuniversity.edu.ng
}

Received 30 August 2018; Accepted 04 October 2018

\begin{abstract}
Retaining talented employees has become a major challenge confronting the management in hospitality industry. Researchers from different climes have advocated for adequate retention strategies such as career growth opportunities, for overcoming the alarming rate of employees' turnover in hotel organisations. However, there is paucity of empirical study on career growth opportunities and employees' turnover intention. To fill this gap, quantitative data were gathered with 327 copies of questionnaire, administered to the frontline employees working in twenty-two 5-star hotels in Nigeria. Structural equation modelling (SEM) was used to test the hypotheses, with descriptive statistics, path analysis, maximum likelihood estimates and goodness of fit indices. The results revealed that all the parameters for career growth opportunities used in this study, inversely interact with turnover intention among the respondents. The findings indicate that organisations should pay adequate attention to career goal progress, professional ability development, promotion speed and remuneration growth of their talented employees. It implies that, these factors are pivotal for saving the cost of hiring new entrants, reduce the rate of turnover intention/actual turnover, and retain experienced high performers in hotel industry. This research established the effects of career growth opportunities on turnover intention in Nigerian context.
\end{abstract}

Keywords: career growth, remuneration growth, career goal progress, professional ability development, promotion speed, employees' turnover intention.

JEL Classification: M1, M5, M52.

\section{Introduction}

Issue of employee turnover has become a general problem in the hospitality industry, as organisations struggle to retain their talented human resources (Jaworski et al. 2018, Tang et al. 2015). Similarly, in the earlier work of Hsu and Tsai (2014), high turnover rate has been identified as a prevalent characteristic among employees in hospitality industry. Gupta and Shaheen (2017) also established that, retaining talented human capital has become a major competition among the $21^{\text {st }}$ century organisations. However, the management, growth and development of every organisation, depend largely on the ability and willingness of its human resources. Human resources can thus be an indispensable tool towards organisational success, especially in the hospitality industry. Inadequate management of human resources lead to increase in the organisation's cost of recruiting and training new entrants, and consequently reduce the quality of service.

According to Ampomah and Cudjor (2015), organisations that fail to make provision for the needs of their high performers; identify their efforts and reward them accordingly, will not only experience low productivity, but also lose them to other organisations. Hence, an increase in turnover rate. The issue of turnover intention and actual turnover has become a major issue confronting the economy, researchers and practitioners especially in hospitality industry in Nigeria (Ohunakin et al. 2016, Akwara et al. 2014). Apart from dearth of empirical work in the hospitality industry in Nigeria, little has been known about human resource management practices in the hospitality sector of the country; because of these, coupled with the high rate of employee turnover intention among employees in hospitality sector in

Copyright (c) 2018 The Authors. Published by VGTU Press.

This is an Open Access article distributed under the terms of the Creative Commons Attribution License (http://creativecommons.org/licenses/by/4.0/), which permits unrestricted use, distribution, and reproduction in any medium, provided the original author and source are credited.. 
Nigeria, this research thus attempted to provide better understanding about the mechanisms for turnover intention. In addition, Nawaz and Pangil (2016) thus advocated for more study on career growth opportunities and employees' turnover intention, moreover, little empirical studies on these two constructs exist in literature (Guan et al. 2015). It is imperative that research should be carried out in the hospitality sector, to establish the influence of talent retention strategies such as career growth opportunities, on employees' turnover intention in a developing economy like Nigeria. Therefore, the objective of this study is to establish the influence of career growth opportunities on employees' turnover intention in the present clime. Figure 1 indicated the schematic model and illustrated the hypotheses for this study.

\section{Literature review}

\subsection{Career growth opportunities and dimensions}

In Biswakarma (2016), career growth was defined as an individual perception of the available opportunities for advancement and development within an organisation. Spector (2003) earlier defined career growth as the continuous improvement in an employee's position in accordance with his/her efforts in gaining requisite skill for performance upgrade. In other words, career growth can be described as the increasing in an employee's career ladder in accordance with the increase in his/her capability building. It can also be regarded as joint effort of both the employees and employers. According to Lips-Wiersma and Hall (2007), growth in employees' career goal is a joint effort of the employees and employers, which requires well organized and formalized arrangement between an individual employee's career needs, and organisational workforce requirements.

This study adopted Weng and Xi (2011) four dimensions of career growth, including: career goal progress (CGP), professional ability development (PAD), promotion speed (PS), and remuneration growth (RG). Career goal progress is the ability of an individual's present employment to assist in the realization of one's career goal, while professional ability development is the ability of the current job to allow an individual to acquire new knowledge and skills. Promotion speed has to do with the availability of promotion as expected by an individual, and remuneration growth is the possibility of increase in rewards and compensations.

\subsection{Turnover intention}

Ismail (2015) defined turnover intention as a subjective estimation of an employee, that has to do with the likelihood of his or her leaving the current employer very soon. According to Takawira et al. (2014), turnover intention is an ideal of an employee leaving the current organisation and seeking employment in another organisation. Turnover intention is the employee's thoughts or plans of leaving a job (Simon et al. 2010). In the opinion of Perryer et al. (2010), turnover intention is the immediate behaviour or attitude before actual turnover, while Samad (2012) regarded turnover intention as the conscious effort of an employee towards seeking alternative appointment outside the current employment. Li et al. (2017) used turnover intention as a model for explaining employees' turnover behaviour for reducing the rate of employee turnover intention among the frontline Casino employees in Macau. Kim (2014) had earlier established supervisor support as an antecedent of employees' turnover intention among the veterans, while personnel management, work-related and external factors are the antecedents for turnover intention of the neophytes in the travel industry. In Ohunakin (2018), it was argued that employee turnover intention is one of the employee's attitudinal or behavioural outcomes which is in accordance with Fishbein and Aizen attitude-behaviour theory of 1975. In Dai et al. (2019), it was argued that promotion opportunity among others significantly correlated with employees' turnover intention.

\subsection{Career growth opportunities and turnover intention}

Woods and De Menezes (1998) and Huselid (1995) argued that career growth opportunities for employee in an organisation do not only assist in shaping employees' attitudes and improve organisational performance, but also propel employee to go extra mile in their given tasks and in-turn leave them with no intention to exit such organisation. It was further expressed in their work, that employees' perception about the investment done by their employer on them, is an

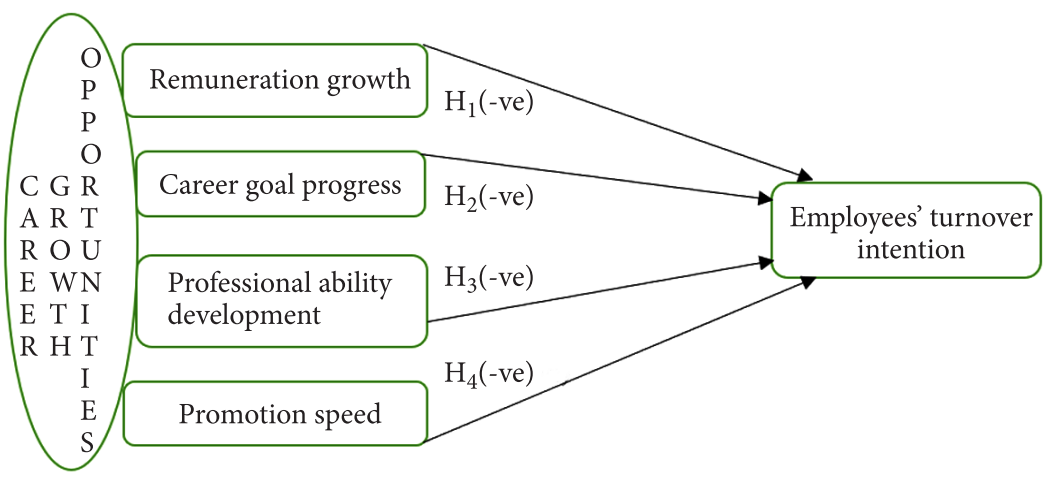

Figure 1. Schematic model (source: Field Survey 2018) 
indication that such employer is interested in their career growth and development. Nouri and Parker (2013) found that career growth opportunities influence employees' job commitment and reduce their turnover intention. Similarly, Karavardar (2014) identified favourable career growth as one of the major tools for retaining employees in an organisation, and consequently reduce their turnover intentions.

According to Omonijo et al. (2015), remuneration was viewed as a strong determinant of employee turnover intention among non-academic staff of higher institution. Heathfield (2017) accentuated that, growth in remuneration according to the input and performance of an individual to the organisation, could serve as a means of reducing employee's turnover intention. Wang et al. (2014) postulated that adequate opportunities for employees in the organisation could lower employees' turnover rate and consequently improve employees' retention in hospitality industry. Karavardar (2014) asserted that organisational ability to provide satisfactory remuneration advancement for the employees, will enhance the employees' sense of belongingness, hence little or no intention to leave the organisation.

Mapelu and Jumah (2013) opined that, when adequate advancement opportunities are available, employees in hospitality industry tend to be more committed to both their works and the organisation, with no intention to leave such organisation. Biswakarma (2016) argued that, provision for advancement in employee's career/professional ability can be used for managing issues of turnover among high performers. In the same vein, Chen et al. (2016) stated that availability of professional ability development for an employee in any organisation, has the potential to increase employee's satisfaction, and further improve the exchange relationship between the organisation and the employees. Hence, there will be little or no intention to leave such organisation.

In Nawaz and Pangil (2016), it was assumed that speed in employees' promotion have the potential to reduce employees' turnover intention, improve their commitment to the organisation and increase their sense of belongingness. Conversely, Karavarda (2014) and Chen et al. (2016) found insignificant impact of career goal progress on employees' turnover intention in their different studies. Based on the aforementioned, the following hypotheses were formulated:

Hypothesis $1\left(\mathrm{H}_{1}\right)$ : Remuneration growth will negatively relate with employees' turnover intention.

Hypothesis $2\left(\mathrm{H}_{2}\right)$ : Career goal progress will have negative association with employees' turnover intention.

Hypothesis $3\left(\mathrm{H}_{3}\right)$ : Professional ability development will have negative relationship with employees' turnover intention.

Hypothesis $4\left(\mathrm{H}_{4}\right)$ : Promotion speed will have inverse relationship with employees' job satisfaction.

\section{Methodology}

\subsection{Participants and procedures}

This empirical study adopted the cross-sectional research design. Pen and paper questionnaires were used to gather data among the employees working in 5-star hotels in Nigeria. Five (5)-star hotels were selected for this study, because they are the apex hotels in Nigeria. Furthermore, for adequate representation, total enumeration method of sampling was adopted in the region where there are limited number of respondents, as adopted in Ohunakin et al. (2018), while proportional stratified sampling technique was used in the region with larger number of respondents. Quantitative data were gathered with four hundred and thirty-eight (438) copies of questionnaire administered to the frontline employees working in twenty-two (22), 5-star hotels in Nigeria. Three hundred and twenty-seven (327) of the sampled questionnaire, were found usable and which indicates $75 \%$ valid retrieval rate. The analysis of this work was done using Stata software version 14.

\subsection{Measuring instrument}

The scales (15-items) developed by Weng and $\mathrm{Hu}$ (2009), were adapted for measuring the four facets of career growth (i.e. career goal progress (CGP), professional ability development (PAD), promotion speed (PS) and remuneration growth (RG)), while the 3-item employees' turnover intention by Mobley et al. (1979) was adopted.

\section{Results}

Table 1 showed that the male respondents were 195 (60.99\%), while the female respondents were 125 (39.01\%).

Table 1. Demographic profile of respondents (source: Field Survey 2018)

\begin{tabular}{|l|l|c|c|}
\hline \multicolumn{2}{|c|}{ Characteristics } & $\mathrm{N}$ & Percent \\
\hline \multirow{4}{*}{ Gender } & Male & 197 & 60.24 \\
& Female & 126 & 38.54 \\
& Missing & 4 & 1.22 \\
& Total & 327 & 100.00 \\
\hline \multirow{5}{*}{ Age } & $20-26$ & 72 & 22.02 \\
& 27-32 & 119 & 36.39 \\
& 33-39 & 93 & 28.44 \\
Highest & 40 and above & 40 & 12.23 \\
Educational & Missing & 3 & 0.92 \\
Level & Total & 327 & 100.0 \\
\hline \multirow{5}{*}{ Marital Status } & B.Sc/B.A & 300 & 91.74 \\
& M.Sc/M.A & 24 & 7.34 \\
& Missing & 3 & 0.92 \\
& Total & 327 & 100.0 \\
\hline \multirow{5}{*}{ Tenure of } & Single & 162 & 49.54 \\
Service & Married & 161 & 49.24 \\
& Mivorced & 4 & 1.22 \\
& Missing & 0 & 0 \\
& Total & 327 & 100.0 \\
\hline & Below 1 year & 73 & 22.32 \\
& 1-3 & 98 & 29.97 \\
& More than 5 years & 71 & 25,69 \\
& Missing & 1 & 0.31 \\
& Total & 327 & 100.0 \\
\hline
\end{tabular}


The study sample represents different age groups from twenty (20) years to above forty (40) years. The largest group of respondents was between ages 27 and 32 with 119 (36.73\%), followed by 33-39, 93 (28.7\%). There are $72(22.2 \%)$ respondents between $20-26$, while there are $40(12.35 \%)$ respondents for age 40 and above. Majority of the respondents were B.Sc/BA degree holders, totalling 300 (92.59\%), while the remaining 24 (7.41\%) had M.Sc/ MBA degree. Respondents representing 162 (49.54\%) were single, 161 (49.24\%) were married, while the remaining 4 (1.22\%) were divorced. Respondents representing 98 (30.06\%) have spent between $1-3$ years, 84 (25.77\%) have spent 3-5 years, 73 (22.39\%) have spent below one year, while the remaining 71 (21.78\%) of the total respondents, have spent more than five years with their organisations.

The descriptive statistics of this study is as illustrated in Table 2. This table shows the number of respondents, mean, standard deviation (SD), and range of score for each of the items in the measuring instrument. There are fifteen items for career growth opportunities (independent variable), i.e. four items for career goal progress (CGP1 - CGP4), four items for professional ability development (PAD1 - PAD4), four items for promotion speed (PS1 - PS4), and three items for remuneration growth (RG1 - RG3). Employees' turnover intention (dependent variable) has three items
Table 2. Descriptive statistics (source: Field Survey 2018)

\begin{tabular}{|l|c|c|c|c|c|}
\hline $\begin{array}{c}\text { Variable } \\
\text { items }\end{array}$ & $\begin{array}{c}\text { No of } \\
\text { Obser- } \\
\text { vations }\end{array}$ & Mean & SD & $\begin{array}{c}\text { Mini- } \\
\text { mum }\end{array}$ & $\begin{array}{c}\text { Maxi- } \\
\text { mum }\end{array}$ \\
\hline CGP1 & 327 & 3.7554 & 1.0830 & 1 & 5 \\
\hline CGP2 & 327 & 3.5932 & 1.1597 & 1 & 5 \\
\hline CGP3 & 327 & 3.5808 & 1.1471 & 1 & 5 \\
\hline CGP4 & 327 & 3.6790 & 1.1357 & 1 & 5 \\
\hline PAD1 & 327 & 3.4159 & 1.2278 & 1 & 5 \\
\hline PAD2 & 327 & 3.7248 & 1.2350 & 1 & 5 \\
\hline PAD3 & 327 & 3.8129 & 1.1470 & 1 & 5 \\
\hline PAD4 & 327 & 3.1896 & 1.2681 & 1 & 5 \\
\hline PS1 & 327 & 4.0736 & 1.0557 & 1 & 5 \\
\hline PS2 & 327 & 3.8957 & 0.9732 & 1 & 5 \\
\hline PS3 & 327 & 3.9083 & 0.9896 & 1 & 5 \\
\hline PS4 & 327 & 4.0214 & 1.0285 & 1 & 5 \\
\hline RG1 & 327 & 3.6349 & 0.9896 & 1 & 5 \\
\hline RG2 & 327 & 3.9449 & 1.0285 & 1 & 5 \\
\hline RG3 & 327 & 3.6554 & 0.9709 & 1 & 5 \\
\hline ETI1 & 327 & 3.1223 & 1.1229 & 1 & 5 \\
\hline ETI2 & 327 & 2.9786 & 1.1915 & 1 & 5 \\
\hline ETI3 & 327 & 3.0245 & 1.2699 & 1 & 5 \\
\hline
\end{tabular}

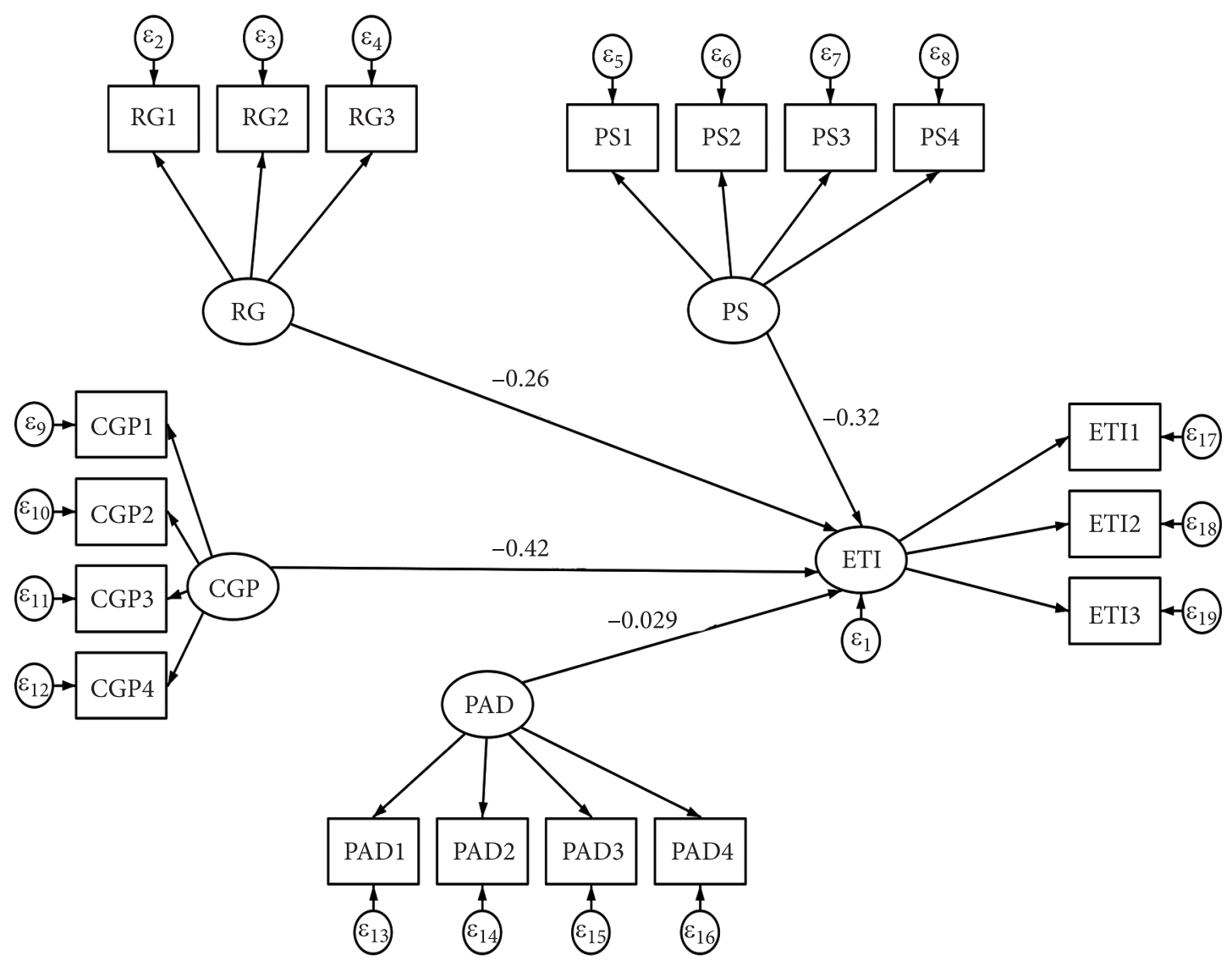

Figure 2. Initial model for career growth opportunities and employees' turnover intention 
(ETI1 - ETI3). The original model with standardized estimates as shown in Figure 2, specifies the relationship of the four facet of career growth (CGP, PAD, PS, RG) on employees' turnover intention (ETI). Table 3 showed the coefficients of correlation between the four dimensions of career growth opportunities (CGP, PAD, PS, RG) and turnover intention.

Table 4 illustrates the structural path coefficients for the four facets of career growth opportunities on employees' turnover intention (CGP $\rightarrow$ ETI, PAD $\rightarrow$ ETI, PS $\rightarrow$ ETI, and $\mathrm{RG} \rightarrow \mathrm{ETI}$ ), for the modified standardized model (Figure
3) gave values of $-0.4452,-0.2977,-0.3532$, and -0.2572 , whereas values of $-0.4244,-0.2898,-0.3192$, and -0.2554 were found for the unmodified standardized model (Figure 2). These gave $\mathrm{R}^{2}$ values of $-45 \%,-30 \%,-35 \%$, and $-26 \%$ for the modified standardized model, and $-42 \%,-29 \%$, $-32 \%,-26 \%$ for unmodified standardized model. The modified standardized model represents the central criterion (Coefficient of Determination: $\mathrm{R}^{2}$ ) for assessing structural models (Klarner et al. 2013), and the predictive validity power of the model (Hair et al. 2012). Although these outcomes were inverse, they were above $25 \%$ according to the

Table 3. Descriptive statistics and correlation of career growth opportunities and turnover intention (source: Field Survey 2018)

\begin{tabular}{|c|c|c|c|c|c|c|c|}
\hline & M & SD & 1 & 2 & 3 & 4 & 5 \\
\hline 1. CGP & 3.652 & 1.231 & $0.489^{* * *}$ & & & & \\
\hline 2. PAD & 3.536 & 1.319 & $0.809^{* * *}$ & $0.564^{* * *}$ & & & \\
\hline 3. PS & 3.975 & 1.128 & $0.557^{\star * *}$ & $0.432^{* * *}$ & $0.614^{* * *}$ & & \\
\hline 4. $\mathrm{RG}$ & 3.745 & 1.012 & $0.463^{* * *}$ & $0.410^{* * *}$ & $0.449^{* * *}$ & $0.557^{\star * *}$ & \\
\hline 5. ETI & 3.042 & 1.196 & $-0.493^{\star * *}$ & $-0.512^{\star * *}$ & $-0.326^{\star * *}$ & $-0.338^{\star * *}$ & $-0.520^{* * *}$ \\
\hline
\end{tabular}

Note: ${ }^{*} \mathrm{p}<.05 .{ }^{* *} \mathrm{p}<.01 .{ }^{* * *} \mathrm{p}<.001$.

Table 4. Maximum likelihood estimates (source: Field Survey 2018)

\begin{tabular}{|c|c|c|c|c|}
\hline \multirow[b]{2}{*}{ Structural path } & \multicolumn{2}{|c|}{ Original Model } & \multicolumn{2}{|c|}{ Modified Model } \\
\hline & Unstandardised & Standardised & Unstandardised & Standardised \\
\hline \multirow{2}{*}{$\mathrm{CGP} \rightarrow \mathrm{ETI}$} & & & & \\
\hline & -0.3738 & -0.4244 & -0.4078 & -0.4452 \\
\hline $\mathrm{PAD} \rightarrow \mathrm{ETI}$ & -0.2637 & -0.2898 & -0.2863 & -0.2977 \\
\hline $\mathrm{PS} \rightarrow \mathrm{ETI}$ & -0.2815 & -0.3192 & -0.3136 & -0.3532 \\
\hline $\mathrm{RG} \rightarrow \mathrm{ETI}$ & -0.2187 & -0.2554 & -0.2473 & -0.2572 \\
\hline \multicolumn{5}{|l|}{ Measurement } \\
\hline ETI1 & 1.0000 & 0.6804 & 1.0000 & 0.6989 \\
\hline ETI2 & 0.9514 & 0.6246 & 0.9146 & 0.6215 \\
\hline ETI3 & 1.5125 & 0.9083 & 1.4066 & 0.8527 \\
\hline CGP1 & 1.0000 & 0.8318 & 1.0000 & 0.8364 \\
\hline CGP2 & 1.0486 & 0.8152 & 0.8945 & 0.7354 \\
\hline CGP3 & 1.0238 & 0.8024 & 0.9004 & 0.7163 \\
\hline CGP4 & 1.0167 & 0.8063 & 1.0052 & 0.8245 \\
\hline PAD1 & 1.0000 & 0.8895 & 1.0000 & 0.7118 \\
\hline PAD2 & 1.3655 & 0.8491 & 0.8957 & 0.7283 \\
\hline PAD3 & 1.3174 & 0.8688 & 0.9012 & 0.6952 \\
\hline PAD4 & 1.1413 & 0.6990 & 1.0256 & 0.7377 \\
\hline PS1 & 1.0000 & 0.7138 & 1.0000 & 0.6765 \\
\hline PS2 & 1.1649 & 0.8975 & 1.0784 & 0.7675 \\
\hline PS3 & 1.2101 & 0.7025 & 1.2715 & 0.8486 \\
\hline PS4 & 1.1091 & 0.6626 & 1.2911 & 0.8054 \\
\hline RG1 & 1.0000 & 0.7608 & 1.0000 & 0.7046 \\
\hline RG2 & 1.0734 & 0.6938 & 0.8071 & 0.7162 \\
\hline RG3 & 1.0803 & 0.7222 & 0.8187 & 0.7118 \\
\hline
\end{tabular}


assertion of Gaur and Gaur (2006), which demonstrate an acceptable or rejection level of prediction in any empirical study. However, all the hypotheses were accepted because, each of the four facets of career growth has significant inverse effect on employee turnover intention in this study.

A good fit was obtained for the model by allowing error covariance of three (3) sets of observed variables to be freely estimated. However, the fit to the data is statistically good with five (5) basic indices which include: RMSEA = 0.047, $\mathrm{TLI}=0.965, \mathrm{CFI}=0.986, \mathrm{SRMR}=0.030, \mathrm{CD}=0.919$ as shown in Table 5. In line with the opinion of Sahin et al. (2014), root mean square error approximation (RMSEA) is one of the three basic indicators for assessing an acceptable model fit. The RMSEA obtained in this study was
0.047. However, this supported the argument of Marsh and Hocevar (1998) that, RMSEA value closer to 0 or under 0.05 indicates an acceptable/good model fit. Therefore, the modified model (Figure 3 ) can be concluded to reproduces the sample covariance matrix in this study.

\section{Discussion}

The study examined the influence of four facet of career growth opportunities including: career goal progress (CGP), professional ability development (PAD), promotion speed (PS) and remuneration growth (RG) on employees' turnover intention (ETI) among professionals in the hospitality sector. A schematic model was developed and

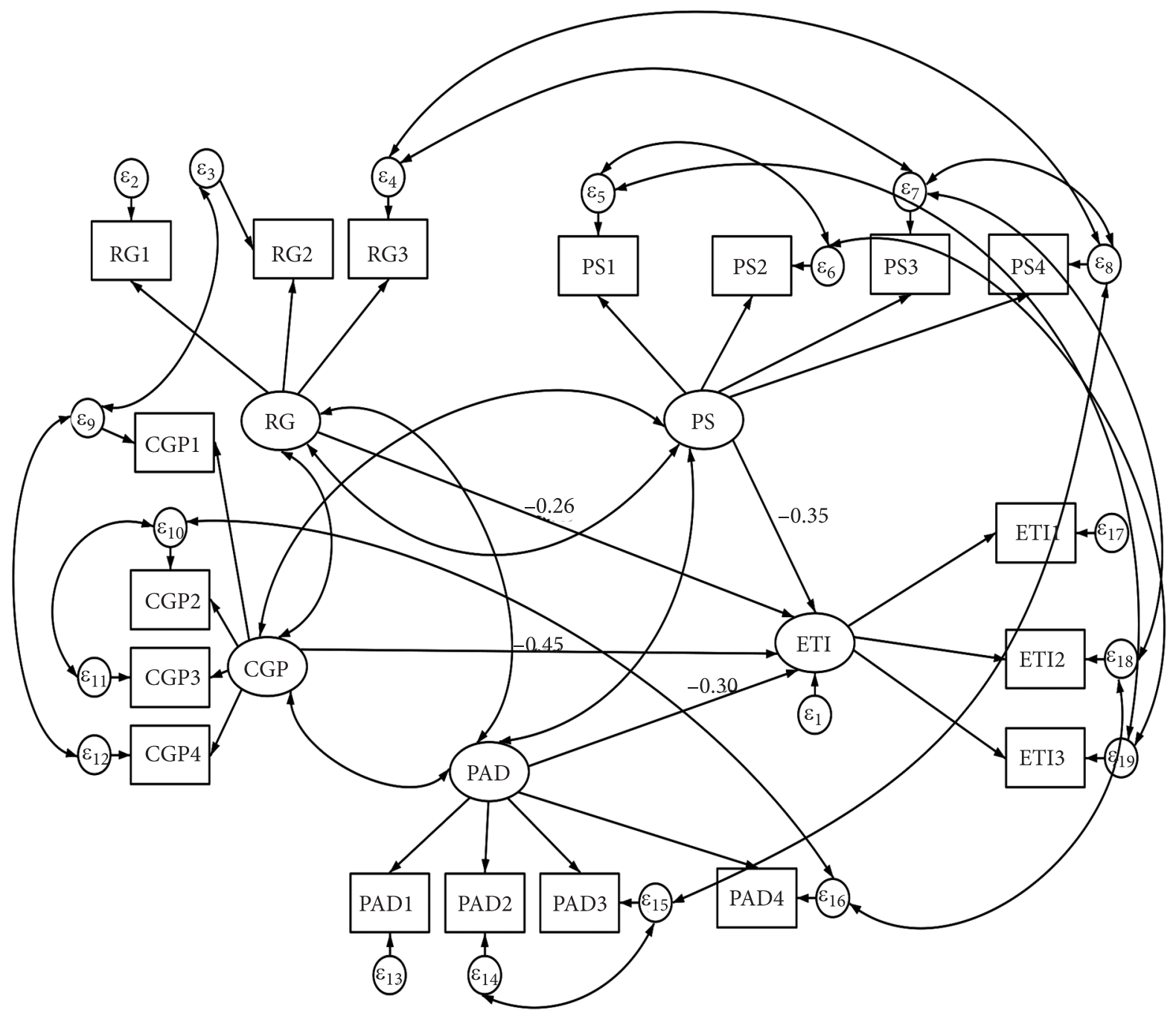

Figure 3. Modified model for career growth opportunities and employees' turnover intention

Table 5. Goodness of fit indices (source: Field Survey 2018)

\begin{tabular}{|l|c|c|c|c|c|c|c|}
\hline \multicolumn{1}{|c|}{ Model } & Chi-Square & RMSEA & P-Close & CFI & TLI & SRMR & CD \\
\hline Initial Model & 260.612 & 0.101 & 0.001 & 0.891 & 0.880 & 0.072 & 0.801 \\
\hline $\begin{array}{l}\text { Modified } \\
\text { Model }\end{array}$ & 104.928 & 0.047 & 0.118 & 0.986 & 0.965 & 0.030 & 0.919 \\
\hline
\end{tabular}


empirically examined with the data gathered from frontline employees, that are working in 5-star hotels in Nigeria. It was found that the four facets of career growth examined in this study, have direct inverse relationship with employees' turnover intention. These indicate that career goal progress, professional ability development, promotion speed, and remuneration growth, associated negatively with employees' turnover intention. This means, the more these facets of career growth are available to the frontline employees, the lower their turnover intention or vice-versa. In other words, for retaining talented frontline employees or reducing their rate of turnover, adequate provision must be made for their career development and growth. These findings are consistent with outcomes of earlier studies such as Griek et al. (2018); Hossain et al. (2018) among bankers in Bangladesh, and the work of Heijden et al. (2018) on nursing sector in Europe.

It can also be observed in this work that, career goal progress revealed the highest level of direct inverse effect on employee turnover intention, with a standardized direct effect of -0.4452 at $p<0.005$. The output revealed that about $79 \%$ of employees' turnover intention can be explained by career goal progress, while the remaining $21 \%$ variability, is because of other factors that cannot be explained by career goal progress. This finding supports the outcomes from Weng and $\mathrm{Hu}$ (2009) and Weng and McElroy (2010), where high correlation was found between career goal progress and employees' turnover intention. In the same vein, the work of Muliawan et al. (2009) on auditors, revealed negative relationship between growth in career goal and turnover intention; observation in the study further encouraged management to be consistent in career goal growth, if they are to retain high performers.

Promotion speed has the second highest inverse effect on employee turnover intention, with a standardized direct effect of -0.3532 at $p<0.005$. This output revealed that $81 \%$ of employees' turnover intention can be explained by promotion speed, and the remaining $19 \%$ variability may be due to other factors that cannot be explained by promotion speed. This outcome is in line with the opinion of Zhang et al. (2005), which stated that speed in talented employee's promotion has the potential to decrease his/her intention to leave the current organisation. Although, in Weng and McElroy (2012), remuneration growth and promotion speed were taken together as one of the facets of career growth opportunities. However, the joint efforts of remuneration growth and promotion speed revealed an inverse relationship with managerial employees' turnover intention among workforce in Chinese companies.

The third direct inverse effect on employee turnover intention is the professional ability development, with a standardized direct effect of -0.2977 at $p<0.005$. The output also revealed that $85 \%$ of employee turnover intention can be explained by professional ability development, while the remaining $15 \%$ can be explained by other factors aside professional ability development. This outcome is consistent with previous studies, such as that of Weng and McElroy (2012), that found inverse significant relationship between professional ability development and turnover intention on managerial employees in People's Republic of China, and the work of Yang et al. (2015) on the impact of work support and organisation career growth on employee turnover intention among Chinese health workers. Their outcomes revealed that, the more the availability of career growth and development, the less the intention of the employee to turnover.

Remuneration growth has fourth inverse relationship with employee turnover intention, having a standardized direct effect of -0.2572 at $p<0.005$. The output of the analysis revealed that $94 \%$ of employee turnover intention can be explained by remuneration growth, and the remaining $6 \%$ can only be explained by other factors apart from remuneration growth. This finding is in accordance with some previous studies, such as Nawaz and Pangil (2016), that found an inverse relationship between remuneration growth and employee turnover intention among faculty members of some selected private higher institutions in Pakistan. The work further concluded that, career related factors such as increase in remuneration growth, perceived fair and just appraisal, are some of the major parameters for reducing employee turnover intention. The work of Karavardar (2014) also found an inverse significant relationship between remuneration growth and employees' turnover intention. Growth in remuneration is thus pivotal for employees' sustainability; as an employee is growing, his/her responsibilities will also be increasing. This therefore requires increase in his/her income to be able to meet these demands.

\section{Conclusions}

The major purpose of this study was to examine the role of career growth opportunities dimensions on employees' turnover intention in Nigeria's hospitality industry. Based on a survey of 327 frontline employees of the twenty-two 5 -star hotels in Nigeria. It is concluded that, growth opportunities (career goal progress, professional ability development, promotion speed and remuneration growth) have inverse influence on employees' turnover intention. Thus, resulted in generalizing the previous findings in this present context, and further reduce the level of inconsistencies in extant literature. This work further established that career growth is one of the major means of responding to the needs of talented employees in hospitality industry and to reduce their intention to leave. This study therefore recommends that, adequate provisions should be made by the management, for the desires and expectations of frontline employees in hospitality industry. Also, these career growth 
opportunities should form a major part of the strategies for retaining employees in organisations, in a bid to combat the problem of turnover, minimize the cost of recruitment and consequently achieve the overall organisational goals and objectives.

\section{Limitations and recommendation for future research}

The findings of this work should be viewed by considering its limitations. First, the data were gathered through selfreported survey; hence, there are possibilities of underestimation or overestimation in the respondents' responses. Secondly, more studies on these constructs is highly essential in other sectors of the economy, such as financial, health, manufacturing and so on, in Nigeria. This is not only for confirming the finding of this study, but also, to know how the four factors of career growth opportunities of Weng and $\mathrm{Hu}$ (2009), will be of much importance in reducing the turnover rate of talented workforce in the country. Thirdly, this study did not examine any moderating or mediating variable; further studies should consider some moderating or mediating variables such as cultural dimensions, demographic characteristics etc., because Nigeria is a diverse country with many cultural differences and demographic characteristics etc. Fourth, other career growth opportunities such as, career commitment, career concerns, perceived alternative job opportunities that were included in Weng et al. (2010), should be examined. Fifth, replication of this study in other African countries will assist in establishing the generalizability of the findings. Lastly, there is a need to further elaborate on the concept of career growth opportunities, by exploring more causal relationships among career growth opportunities and other variables.

\section{Implication of findings}

The outcomes of this study have some implications for organisations generally, and in particular the hospitality industry. It should also be noted that, there may be need for this study to be extended to other sectors to determine whether the findings in this work can be generalized across industries or sectors of the country. Since the issue of turnover has become a general concern for both the developing and developed nations, it requires adequate management. The findings from this study provide adequate information to the management in the hospitality industry, career counsellors, and researchers, towards the state of career growth among employees in Nigeria. It is worth noting that, career growth opportunities have the potentials for retaining talented employees in Nigerian workplace. It is therefore suggested for both the publicly and privately-owned organisations, to recognize, invest and embrace relevant career growth opportunities for the benefit of their workforce to reduce the rate of turnover intention and actual turnover. This will assist these organisations to minimize the cost of replacement and hence, retain good employees.

\section{Acknowledgement}

We sincerely appreciate Covenant University for providing enabling platform to carry out this research.

\section{References}

Akwara AF, Biu MI, Abutu G, Okwelume R (2014) Human resource management and development of the tourism and hospitality industry in Nigeria. Journal of Good Governance and Sustainable Development in Africa 2 (1): 97-105 http:// www.rcmss.com ISSN: 2346-724X (Print) ISSN: 2354-158X (Online).

Ampomah, P, Cudjor SK (2015) The effect of employee turnover on organizations (case study of electricity company of Ghana, Cape Coast). Asian Journal of Social Sciences and Management 2 (1): 21-24 http://www.asianonlinejournals. com/index.php/AJSSMS

Biswakarma G (2016) Organisational career growth and employees' turnover intentions: an empirical evidence from Nepalese private commercial Banks. International Academic Journal of Organisational Behaviour and Human Resource Management 3 (2): 10-26 www.iaiest.com

Chen J, Hou Z, Li X, Kathi J, Lovelace KJ, Liu Y, Wang Z (2016) The role of career growth in Chinese new employee's turnover process. Journal of Career Development 43 (1): 11-25. https:// doi.org/10.1177/0894845315571412

Dai Y, Zhuang, W, Huan T (2019) Engage or quit? The moderating role of abusive supervision between resilience, intention to leave and work engagement. Tourism Management 70: 69-77. https://doi.org/10.1016/j.tourman.2018.07.014

Gaur AS, Gaur SS (2006) Statistical methods for practice and research: a guide to data analysis using SPSS. London: Sage.

Griek OHV, Clauson MG, Eby LT (2018) Organisational career growth and proactivity. A typology for individual career development. Journal of Career Development. https://doi. org/10.1177/0894845318771216

Guan Y, Zhou W, Ye L, Jiang P, Zhou Y (2015) Perceived organisational career management and career adaptability as predictors of success and turnover intention among Chinese employees. Journal of Vocational Behaviour 88: 230-237. https://doi.org/10.1016/j.jvb.2015.04.002

Gupta M, Shaheen M (2017) Impact of work engagement on turnover intention: moderation by psychological capital in India. Business: Theory and Practice 18: 136-143. https://doi. org/10.3846/btp.2017.014

Hair JF, Sarstedt M, Ringle CM, Mena JA (2012) An assessment of the use of partial least squares structural equation modelling in marketing research. Journal of the Academy of Marketing Science 40 (3): 414-433. https://doi.org/10.1007/ s11747-011-0261-6

Heathfield SM (2017) Want to know the 8 top reasons why employees quit their jobs? https://www.thebalance.com/whydo-employees-quit-their-jobs- 1918000 
Heijden, BIJM, Peeters MCW, Blanc PML, Breukelen JWMV (2018) Job characteristics and experience as predictors of occupational turnover inteion and occupational turnover in the European nursing sector. Journal of Vocational Behavior 108: 108-120. https://doi.org/10.1016/j.jvb.2018.06.008

Hossain, SMK, Roy MK, Das PK (2018). Factors affecting employee's turnover intention in banking sector of Bangladesh: an empirical analysis. ASA University Review 11 (2): 1-14.

Hsu M, Tsai Y (2014) Career satisfaction and organisational commitment among hotel employees in Taiwan. Journal of Hotel and Business Management 3 (1): 1-4. https://doi. org/10.4172/2169-0286.1000107

Huselid MA (1995) The impact of human resource management practices on turnover, productivity and corporate financial performance. Academy of Management Journal 38: 635-672. https://doi.org/10.5465/256741

Ismail H (2015) Job insecurity, burnout and intention to quit. International Journal of Academic Research in Business and Social Sciences 5 (4): 310-324. https://doi.org/10.6007/ IJARBSS/v5-i4/1574

Jaworski C, Ravichandran S, Karpinski AC, Singh S (2018) The effects of training satisfaction, employee benefits, and incentives on part-time employees' commitment. International Journal of Hospitality and Management 74: 1-12. https://doi. org/10.1016/j.ijhm.2018.02.011

Karavardar G (2014) Organisational career growth and turnover intention: an application in audit firms in Turkey. International Business Research 7 (9): 67-76. https://doi.org/10.5539/ ibr.v7n9p67

Kim N (2014) Employee turnover intention among newcomers in travel industry. International Journal of Tourism Research 16 (1): 56-64. https://doi.org/10.1002/jtr.1898

Klarner P, Sarstedt M, Hoeck M, Ringle CM (2013) Disentangling the effects of team competences, team adaptability, and client communication on the performance of management consulting teams. Long Range Planning 46 (3): 258-286. https://doi. org/10.1016/j.lrp.2013.03.001

Li J, Kim WG, Zhao X (2017) Multilevel model of management support and casino employee turnover intention. Tourism Management 59: 193-204. https://doi.org/10.1016/j.tourman.2016.08.006

Lips-Wiersma M, Hall DT (2007) Organisational career development is not dead: a case study on managing the new career during organisational change. Journal of Organisational Behaviour 28 (6): 771-792. https://doi.org/10.1002/job.446

Mapelu IC, Jumah L (2013) Effect of training and development on employee turnover in selected medium sized hotels in Kisumu City, Kenya. Journal of Tourism, Hospitality and Sports 1 (23): 43-48.

Marsh HW, Hocevar D (1988) A new, more powerful approach to multitrait-multimethod analyses: application of second-order confirmatory factor analysis. Journal of Applied Psychology 73 (1): 107-17. https://doi.org/10.1037/0021-9010.73.1.107

Mobley WH, Griffeth RW, Hand HH, Meglino BM (1979) Review and conceptual analysis of the employee turnover process. Psychological Bulletin 86: 493-522. https://doi. org/10.1037/0033-2909.86.3.493

Muliawan AD, Green PF, Robb DA (2009) The turnover intention of information system auditors. International Journal of
Accounting Information Systems 10 (3): 117-136. https://doi. org/10.1016/j.accinf.2009.03.001

Nawaz MS, Pangil F (2016) The relationship between human resource development factors, career growth and turnover intention: the mediating role of organisational commitment. Management Science Letters 6: 157-176. https://doi. org/10.5267/j.msl.2015.12.006

Nouri H, Parker RJ (2013) Career growth opportunities and employee turnover intentions in public accounting firms. The British Accounting Review, 1-11. https://doi.org/10.1016/j. bar.2013.03.002

Ohunakin F (2018) Talent retention strategies and employees' behavioural outcomes in Nigeria's hospitality industry (Unpublished Doctoral Thesis). Department of Business Studies, School of Business, College of Development Studies, Covenant University, Ota, Ogun State, Nigeria.

Ohunakin F, Adeniji AA, Oludayo OA, Osibanjo AO (2018) Survey dataset on leadership styles and job satisfaction: the perspective of employees of hospitality providers. Data in Brief 19: 2178-2188. https://doi.org/10.1016/j.dib.2018.06.033

Ohunakin F, Adeniji AA, Akintayo DI (2016) Transactional leadership style and employee job satisfaction among universities' guest houses in South-West Nigeria. $3^{\text {rd }}$ International Conference on African Development Issues, 368-371.

Omonijo DO, Oludayo OA, Eche GO, Uche OC, Ohunakin F (2015) Intentional turnover of the administrative staff in a private faith-based higher institution, Southwest Nigeria. Mediterranean Journal of Social Sciences 6 (2): 424-434. https://doi.org/10.5901/mjss.2015.v6n2s1p424

Perryer C, Jordan C, Firns I, Travaglione A (2010) Predicting turnover intentions: the interactive effects of organisational commitment and perceived organisational support. Management Research Review 33 (9): 911-923. https://doi. org/10.1108/01409171011070323

Samad S (2012) The role of organisational commitment in the relationship between job satisfaction and turnover intention. European Journal of Social Sciences 30 (1): 125-135.

Sahin I, Akyurek CE, Yavuz S (2014) Assessment of effect of leadership behaviour perceptions and organisational commitment of hospital employees on job satisfaction with structural equation modelling. Journal of Health Management 16 (2): 161-182. https://doi.org/10.1177/0972063414526111

Simon M, Müller BH, Hasselhorn HM (2010) Leaving the organisation or the profession - a multilevel analysis of nurses' intentions. Journal of Advanced Nursing 66 (3): 616-626. https://doi.org/10.1111/j.1365-2648.2009.05204.x

Spector PE (2003) Industrial and organizational psychology: research and practice ( $3^{\text {rd }}$ ed). New York: John Wiley \& Sons, Inc.

Takawira N, Coetzee M, Schreuder D (2014) Job embeddedness, work engagement and turnover intention of staff in a higher education institution: an exploratory study. SA Journal of Human Resource Management 12 (1): 1-10. https://doi. org/10.4102/sajhrm.v12i1.524

Tang G, Cai Z, Liu Z, Zhu H, Yang X, Li J (2015) The importance of ethical leadership in employees' value congruence and turnover. Cornell Hospitality Quarterly 56 (4): 397-410. https:// doi.org/10.1177/1938965514563159

Wang CJ, Tsai HT, Tsai MT (2014) Linking transformational leadership and employee creativity in the hospitality industry: 
the influences of creative role identity, creative self-efficacy, and job complexity. Tourism Management 40: 79-89. https:// doi.org/10.1016/j.tourman.2013.05.008

Weng QB, Hu B (2009) The structure of career growth and its impact on employees' turnover intention. Industrial Engineering and Management 14: 14-21.

Weng Q, Xi Y (2011) Career growth study: scale development and validity test. Management Review 22 (10): 22-31.

Weng Q, McElroy JC, Morrow PC, Liu R (2010) The relationship between career growth and organisational commitment. Journal of Vocational Behaviour 77: 391-400. https://doi. org/10.1016/j.jvb.2010.05.003

Weng Q, McElroy J (2012) Organisational career growth, affective occupational commitment and turnover intentions. Journal of
Vocational Behaviour 80: 256-265. https://doi.org/10.1016/j. jvb.2012.01.014

Woods S, De Menezes L (1998) High commitment management in the UK: evidence from the workplace industrial relations survey and employers' manpower and skills practices survey. Human Relation 51: 485-515. https://doi. org/10.1023/A:1016941914876

Yang Y, Liu Y, Liu J, Zhang H (2015) The impact of works support and organisation career growth on nurse turnover intention in China. International Journal of Nursing Sciences (2): 134139. https://doi.org/10.1016/j.ijnss.2015.04.006

Zhang YC, Li SL, Liu P, Deng JX (2005) Interaction effects of promotional chances on marketing employee turnover intention. Chinese Journal of Management 5: 576-581. 